\title{
Editor's Note: Which Way is West?
}

Rachel L. Stein

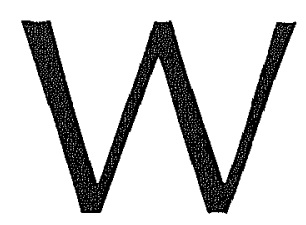
hen I was a child, summer was a time of conquest - a symbolic period of expansion. In between the completion of one school year and the trepidation of the coming fall, were two glorious months where my only task was the suppression of all prudent instincts. Summer was a time of excess: too much sun, too much risk, and too much consumption.

\section{The}

George

Washington

University

Journal

of Public

Administration

Each August, as the weather started to turn cold, my family would head west to visit my grandparents in Los Angeles. At the foot of the hill on which my grandparents live was a local supermarket called Westward HO!. The sign was shaped like a covered wagon and it lit up like a beacon to the westward traveller. "Come here" it said. "This is the land of opportunity." As time went on, bulbs burned out, the sign cracked, and all the big chains moved onto nearby Ventura Boulevard. But Westward HO! remained steadfast; a lasting symbol of the spirit of more. 


\section{From the ashes}

of over

consumption a

new question

has risen:

"which way is

west?"
In the extended summer of American economic and physical expansion, opportunity successfully subjugated prudence. Now there is no more - at least not as we once knew it. Summer is made special by the fact that it is bounded; it's high time to formally welcome the autumn of the new and different world in which we are already living.

From the ashes of over consumption a new question has risen: "which way is westward? 'The answer is unfamiliar, but the territory is just as vast. The new collective west points inward. It is the rebuilding of the cities that already exist; the rethinking of the way we presently consume; the engagement of real policy discussions about the information age that surrounds us.

Hidden in the chaos of this explosion lies a tremendous opportunity for creativity. While there are no "best practices" or "benchmarks" for redefining citizenship, public administration as a discipline is perfectly suited to this dialogue.

As a student of public administration, I am encouraged by a discipline in which the "defining literature" is the literature of free inquiry. In keeping with this tradition, the original student scholarship in this volume explores the issues, sub-texts, and policies relevant to managing in an ever-changing world. Ken Kero examines the politics of trade in the context of globalization and the New Economy. Mike Velasquez and Dina Dariotis propose an original policy for universal access to information technology services. Danielle Bartoni argues that traditional transportation policies are no longer effective and makes a compelling case for congestion pricing on America's highways during peak periods of travel. Alena Svab outlines a policy for establishing federal child care standards, and Blythe Eaman, Suzanne Sack, and Heather Higginbottom look at the processes and players involved in one community's struggle to rebuild. In the annual Supreme Court Review, Van Lawrence reviews cases of compelling interest to public administration, including Clinton $v$. Jones and Printz $v$. United States.

$I$ am deeply grateful for the support of numerous people whose talent and spirit fill these pages. My first and most profound thanks are to Jill Kasle, who served with distinction as a mentor, an editor, a source of good humor, and a friend. Professor Kasle encouraged our creativity and initiative but also provided assistance and wisdom we gladly accepted. Managing Editor Lynn Bagorazzi was a paragon of fiscal sense, organization, and support throughout the year, but I am most indebted to Lynn for her perfectly timed and brilliantly wry sense of humor. Thanks also go to Amy Downey, who goes above and beyond in every endeavor. Her infallible assistance at the end is truly appreciated.

As a student-produced academic journal, the collaborative efforts of the editorial board are the heart and soul of this publication. I would like to thank the article editors - Lisa 
Gisvold, Lisa Downing, Karen Strickk, Suzanne Payne, and Amy Downey - for all of their hard work and the associate editors - Meredith McWade, Peter Troedsson, Judy Greenbaum, and Tess Fallon - for their precise fact-checking and citation formatting.

On behalf of the entire journal staff and the students in the department of public administration whose original scholarship is highlighted in this volume, I would like to thank those members of the faculty and administration whose constant support has made the publication of Policy Perspectives possible: Stephen Joel Trachtenberg, President of The George Washington University; Jed Kee, Interim Dean of the School of Business and Public Management and a professor in the Department of Public Administration; and Dr. Kathryn Newcomer, Chair of the Department of Public Administration. Dr. Newcomer's confidence in the scholarship and talents of her students is a defining component of the program.

The warmth and support I received from faculty in the Department of Public Administration was unparalleled. My gratitude is owed to several faculty members: to Cynthia McSwain, a teacher in the truest sense; to Michael Harmon, a wonderful source for questions on vocabulary and grammatical information and, most importantly, tremendous humor and warmth; to Bayard Catron for a great year of learning together; to Michele Moser for her fine conflict resolution guidance; to Roz Kleeman for keeping me entertained; and to the rest of the faculty who knew when to offer a supportive smile.

Without the technical assistance of Jonathan Skrmetti, Policy Perspectives would have been a single illuminated manuscript, and Michelle Harris of National Geographic contributed to the grammatical integrity of the journal through her training efforts. Pam Brown, Richard Hylton, and Sarah Sarmiento are owed thanks for many, many moments of support. Clorinda Haug was wonderfully patient with me; an editor with the heart of an artist and ten thumbs for expressing my vision.

I would also like to thank all of the policy professionals who served as peer reviewers for the original manuscripts in this joumal. Their expertise and criticism is an invaluable part of the journal and the learning process of being published.

My final thanks are to the people whose personal support encouraged me in this role and in every area of my life: Meredith McWade, who knows me as well as I know myself and is well-versed in not taking me too seriously; Jonathan Dickinson, my best friend, who taught me what it means to stick it out, and whose love and encouragement fill my days even from a distance; my grandparents - Jinx, Allen, Ada, and Joe - especially Joe whose belief in me has shaped me; my brother David; and finally, my outstanding parents whom I can never repay for the love, belief, and possibility they have given me - and for the fact that they would never ask.

\section{Hidden in the}

chaos of this

explosion lies a

tremendous

opportunity for

creativity. While

there are no

"best practices"

or "benchmarks"

for redefining

citizenship,

public

administration as

a discipline is

perfectly suited

to this dialogue. 
